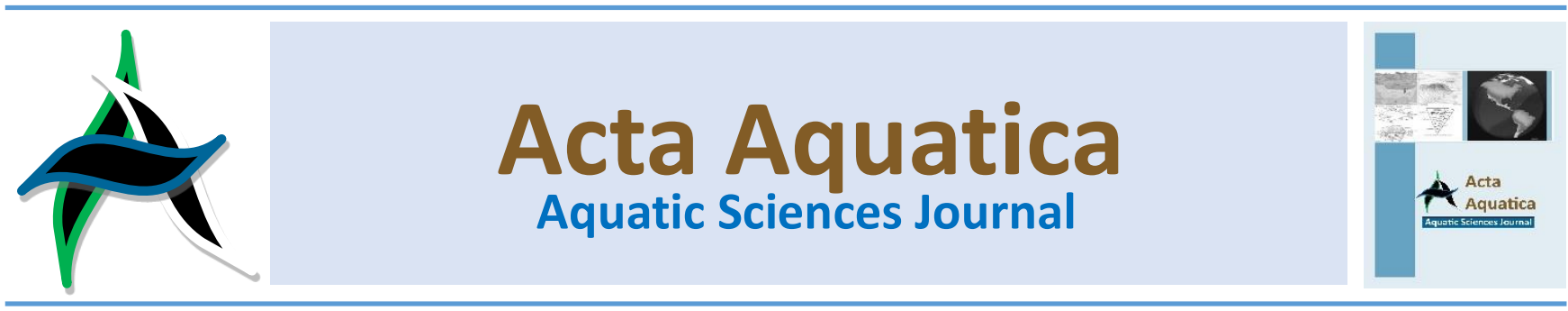

\title{
Dekomposisi serasah daun mangrove Rhizophora apiculata di Desa Bagan Asahan, Kecamatan Tanjungbalai, Kabupaten Asahan, Provinsi Sumatera Utara
}

\section{Decomposition of mangrove leaf litter Rhizophora apiculata in Bagan Asahan Village, Tanjungbalai District, Asahan Regency, North Sumatera Province}

\author{
Kusuma Widya Sari ${ }^{a}{ }^{*}$, Yunasfi $^{\text {a }}$ dan Ani Suryanti ${ }^{\text {b }}$ \\ a Program Studi Manajemen Sumberdaya Perairan, Fakultas Pertanian, Universitas Sumatera Utara \\ ${ }^{b}$ Program Studi Sosial Ekonomi Perikanan, Fakultas Ilmu Kelautan dan Perikanan, Universitas Maritim Raja Ali Haji
}

\begin{abstract}
Abstrak
Mangrove menghasilkan serasah yang akan mengalami proses dekomposisi yang kemudian dimanfaatkan sebagai sumber hara bagi tanaman dan juga merupakan sumber makanan bagi ikan serta invertebrata yang penting. Tujuan dari penelitian ini adalah untuk mengukur dekomposisi serasah daun $R$. apiculata dan mengetahui kandungan unsur hara karbon $(C)$, nitrogen $(N)$ dan fosfor (P) pada serasah daun Rhizophora apiculata yang dilepas selama proses dekomposisi. Penelitian dilakukan pada bulan Februari hingga Mei 2017 di Desa Bagan Asahan Kecamatan Tanjungbalai Kabupaten Asahan Provinsi Sumatera Utara. Penentuan stasiun penelitian menggunakan metode purposive sampling pada tiga stasiun dengan penentuan stasiun berdasarkan pengamatan ketersediaan jenis mangrove $R$. apiculata. Hasil penelitian menunjukkan laju dekomposisi serasah daun $R$. apiculata pada hari ke-90 yaitu pada stasiun I bernilai 13,04 stasiun II bernilai 11,42 dan stasiun III bernilai 10,24 . Kandungan unsur hara karbon selama proses dekomposisi 90 hari yaitu stasiun I sebesar $16,24 \%$, stasiun II sebesar $15,29 \%$ dan stasiun III sebesar 15,42 \%. Unsur hara nitrogen yang terdekomposisi pada hari ke 90 yaitu stasiun I sebesar 2,69\%, stasiun II sebesar 2,57 \% dan stasiun III sebesar 2,75\%. Kandungan unsur hara fosfor selama proses dekomposisi 90 hari yaitu stasiun I 0,02 \%, stasiun II 0,02\% dan stasiun III 0,01 \%.
\end{abstract}

\begin{abstract}
Mangroves produced litter that will undergo decomposition process which used as a source of nutrients for plants and also source of food for fish and important invertebrates. The purpose of this research is to measure the decomposition of Rhizophora apiculata leaf litter and to know the content of carbon (C), nitrogen $(\mathrm{N})$ and phosphorus $(\mathrm{P})$ nutrient in leaf litter of $R$. apiculata released during the decomposition process. The research was conducted from February to May 2017 in Bagan Asahan Village, Tanjungbalai District, Asahan Regency, North Sumatera Province. The method of this research used purposive sampling and determined three stations sampling based on observation of availability $R$. apiculata mangrove species. The result showed that decomposition rate of $R$. apiculata leaf on the 90 day at station I was 13,04 , station II was 11,42 , and station III was 10,24 . The content of carbon nutrients during the 90 day decomposition process in station I was $16.24 \%$, station II was $15.29 \%$ and station III was $15.42 \%$. Nitrogen nutrient elements decomposed on the 90 day were station I was $2.69 \%$, station II was $2.57 \%$ and station III was $2.75 \%$. Phosphorus nutrient content during 90 day decomposition process was $0,02 \%$ for station I, $0,02 \%$ for station II and 0,01\% for station III.
\end{abstract}

Keywords: litter; decomposition; Rhizophora apiculata

\footnotetext{
* Korespondensi: Program Studi Manajemen Sumberdaya Perairan, Fakultas Pertanian, Universitas Sumatera Utara.

JI. Prof. A. Sofyan No.3, Kampus USU, Medan 20155.

Tel: +62-61-8213236 Fax: +62 618211924

e-mail: kusumawidya2818@gmail.com
}

\section{Pendahuluan}

Mangrove merupakan sumberdaya alam yang khas di daerah pantai dan muara sungai yang memiliki fungsi sangat penting baik secara ekologi dan ekonomi bagi masyarakat. Ekosistem hutan mangrove secara ekologi sebagai habitat berbagai organisme. Zonasi mangrove tersusun dari beragam spesies satu diantaranya adalah Rhizhopora apiculata yang termasuk kedalam famili Rhizophoraceae. $R$. apiculata merupakan satu diantara spesies mangrove yang terdapat di Desa Bagan Asahan. 
Serasah daun mangrove diketahui berperan penting dalam transfer bahan organik dari vegetasi ke dalam tanah. Menurut Sa'ban et al. (2013) produksi serasah hutan mangrove di Indonesia diduga sekitar 40,40 C/ha/hari sampai 45,50 kg $\mathrm{C} /$ ha/hari dan untuk tanaman Rhizophora sp. produksi serasah bersihnya adalah 20,80 sampai 25,00 ton $\mathrm{C} /$ ha/tahun. Hutan mangrove di Indonesia menghasilkan produktifitas sekitar 20,50 ton/ha/tahun sampai 29,35 ton/ha/tahun.

Serasah yang dihasilkan mangrove nantinya akan terdekomposisi. Proses dekomposisi serasah mangrove dimulai dari penghancuran yang dilakukan oleh makrobentos kemudian serasah akan terpotong-potong menjadi ukuran yang lebih kecil. Dekomposisi dilanjutkan dengan proses biologi yang dilakukan oleh bakteri dan fungi sebagai dekomposer untuk menguraikan partikel-partikel organik dengan mengeluarkan enzim sehingga dapat menguraikan bahan organik menjadi protein. Hasil dekomposisi tidak hanya dimanfaatkan sebagai sumber hara bagi tanaman tetapi juga merupakan sumber makanan bagi ikan dan invertebrata yang penting. Tujuan dari penelitian ini adalah Untuk mengukur dekomposisi serasah daun $R$. apiculata di Desa Bagan Asahan Kecamatan Tanjungbalai Kabupaten Asahan Provinsi Sumatera Utara dan untuk mengetahui kandungan unsur hara karbon $(C)$, nitrogen $(N)$ dan fosfor $(P)$ pada serasah daun $R$. apiculata yang dilepas selama proses dekomposisi.

\section{Bahan dan metode}

\subsection{Waktu dan tempat}

Penelitian ini dilaksanakan selama tiga bulan (Februari 2017 sampai April 2017). Pengambilan sampel akan dilakukan di Desa Bagan Asahan Kecamatan Tanjungbalai Kabupaten Asahan Provinsi Sumatera Utara (Gambar 1). Analisis unsur hara C, N dan P dilakukan secara Ex situ di Laboratorium Riset dan Teknologi Fakultas Pertanian, Universitas Sumatera Utara.

\subsection{Metode penelitian}

\subsubsection{Pengambilan sampel serasah daun mangrove}

Pengambilan serasah daun mangrove dilakukan dengan cara mengambil langsung daun yang sudah gugur secara alami di lantai hutan mangrove pada setiap stasiun pada petakan $5 \mathrm{~m} \times 5$ $\mathrm{m}$ untuk membatasi daerah pengambilan daun $R$. apiculata. Daun yang diambil berasal dari semua jenis ukuran mangrove yang ada (pohon, pancang, dan semai). Serasah daun $R$. apiculata yang sudah terkumpul kemudian ditimbang seberat $50 \mathrm{~g}$ lalu dimasukkan kedalam kantong serasah (litter bag). Setelah daun dimasukkan, kantong serasah di jahit dan di beri lubang pada dua sisi kantong agar kantong-kantong dapat dihubungkan dengan tali. Kemudian kantong yang sudah berisi serasah ditempatkan sebanyak 18 kantong per stasiun lalu diikatkan dengan erat pada akar mangrove $R$. apiculata yang berukuran diameter $>10 \mathrm{~cm}$ agar pada saat pasang kantong serasah tidak terbawa arus. Prosedur selama penelitian dapat dilihat pada Lampiran 2.

Untuk mengetahui dekomposisi serasah daun $R$. apiculata dilakukan dengan pengamatan 15 hari sekali selama 90 hari dengan interval waktu 15 hari sekali $(0,15,30,45,60,75$, dan 90 hari) sebanyak 3 kantong per stasiun yang diambil secara acak. Setiap selesai waktu pengambilan, serasah dari litter bag dikeluarkan dibilas dengan air lalu ditiriskan. Sampel serasah selanjutnya ditimbang berat basahnya, dan dimasukkan kedalam amplop sampel. Kemudian serasah tersebut dibawa ke laboratorium untuk dikeringkan dalam oven pada suhu 105 으 hingga beratnya konstan, lalu ditimbang berat keringnya.

\subsubsection{Pengumpulan data}

Data yang dikumpulkan adalah data berat basah dan berat kering serasah daun mangrove $R$. apiculata yang telah terdekomposisi selama 90 hari. Data yang dianalisis adalah kandungan unsur hara $\mathrm{C}, \mathrm{N}$ dan $\mathrm{P}$ dalam serasah daun mangrove $R$. apiculata dan parameter fisika-kimia perairan. Pengumpulan data kualitas air dilakukan secara in situ dan pengamatan laboratorium

\subsubsection{Pengambilan data parameter fisika dan kimia perairan}

Pengukuran parameter fisika kimia air dilakukan pada setiap stasiun selama penelitian. Pangambilan dilakukan pada saat air pasang ketika lantai hutan mangrove dalam keadaan tergenang, dilakukan sebanyak 6 kali dengan interval waktu 15 hari selama 3 bulan. Parameter fisika kimia perairan yang diukur dapat dilihat pada Tabel 1.

Gambar 1. Lokasi penelitian 
Tabel 1.

Parameter fisika kimia perairan

\begin{tabular}{lccc}
\hline Parameter fisika-kimia & Satuan & Alat & Tempat analisis \\
\hline Suhu & ${ }^{\circ} \mathrm{C}$ & Thermometer & In Situ \\
DO & $\mathrm{mg} / \mathrm{I}$ & DO Meter & In Situ \\
Salinitas & $\mathrm{ppt}$ & Hand refraktometer & In Situ \\
$\mathrm{pH}$ & - & $\mathrm{pH}$ Meter & In Situ \\
\hline
\end{tabular}

\subsection{Analisis data}

Pengamatan persentase dekomposisi serasah pada daun mangrove $R$. apiculata menggunakan rumus Boonruang (1984), yaitu:

$$
\mathrm{Y}=\frac{\mathrm{BA}-\mathrm{BK}}{\mathrm{BA}} \mathrm{x} 100
$$

Keterangan:

$Y$ : persentase serasah daun yang mengalami dekomposisi (\%)

$\mathrm{BA}$ : berat kering awal penimbangan $(\mathrm{g})$

BK : berat kering akhir penimbangan (g)

Pendugaan nilai konstanta laju dekomposisi serasah dilakukan menurut persamaan Olson (1963) berikut ini:

$$
\begin{gathered}
X t=X 0 \cdot e^{-k t} \\
\text { Jadi }: \ln (X t / X 0)=-k t
\end{gathered}
$$

Keterangan :

$\mathrm{Xt}$ : berat serasah setelah periode pengamatan ke- $t$

XO : berat serasah awal

e : bilangan logaritma natural $(2,72)$

k : nilai laju dekomposisi

$\mathrm{t}$ : periode pengamatan

\subsubsection{Analisis unsur hara karbon, nitrogen dan fosfor}

Analisis unsur hara karbon, nitrogen, dan fosfor dilakukan di Laboratorium Dasar IImu Tanah Fakultas Pertanian Universitas Sumatera Utara. Penentuan kadar unsur hara C dilakukan berdasarkan kehilangan bobot bahan organik karena pemanasan. Analisis kandungan unsur hara $\mathrm{C}$ organik pada daun dilakukan dengan metode Walkley and Black (Mukhlis, 2007):

$$
\text { C organik }=5 \times\left(1-\frac{T}{S}\right) \times 0,003 \times \frac{1}{0,77} \times \frac{100}{B C D}
$$

\section{Keterangan :}

$\mathrm{T} \quad$ : volume titrasi $\mathrm{Fe}\left(\mathrm{NH}_{4}\right)_{2}\left(\mathrm{SO}_{4}\right)_{2} 0.5 \mathrm{~N}$ dengan daun

$\mathrm{S} \quad$ : volume titrasi $\mathrm{Fe}\left(\mathrm{NH}_{4}\right)_{2}\left(\mathrm{SO}_{4}\right)_{2} 0.5 \mathrm{~N}$ dengan blanko (tanpa daun)

0,003 : $1 \mathrm{ml} \mathrm{K}{ }_{2} \mathrm{Cr}_{2} \mathrm{O}_{7} 1 \mathrm{~N}+\mathrm{H}_{2} \mathrm{SO}_{4}$ mampu mengoksidasi 0,003 g C-Organik

$1 / 0,77$ : metode ini hanya $77 \%$ C-Organik yang dapat dioksidasi

BCD : berat contoh daun

Penentuan kadar Nitrogen total dilakukan dengan menggunakan metode Kjelldahl (Mukhlis, 2007):

$$
\text { Kadar } \mathrm{N} \text { dalam daun }=\frac{\mathrm{a} \times 0,02 \times 14}{\mathrm{~b}}
$$

\section{Keterangan :}

\footnotetext{
a : selisih volume (ml)

b : bobot bahan kering dalam 0,1 gr tepung daun

0,02 : normalitas $\mathrm{HCl}$ (sebelumnya distandarisasi terlebih dahulu untuk mengetahui nilai normalis yang tepat)
}

Sedangkan penentuan unsur Fosfor dilakukan dengan didestruksi basah (Mukhlis, 2007):

$$
\begin{aligned}
\mathrm{P} \text { daun }(\%) & =\mathrm{P} \text { larut } \times \frac{50}{0,25} \times \frac{50}{0,25} \times 10^{-4} \\
& =\mathrm{P} \text { larutan } \times 0,2
\end{aligned}
$$

\section{Hasil dan pembahasan}

\subsection{Laju dekomposisi}

Penurunan bobot basah secara fisik menunjukkan sisasisa cercahan serasah daun $R$. apiculata yang semakin lama semakin berubah bentuk menjadi partikel-partikel halus selama periode pengamatan hari ke 15 sampai hari ke 90 . Perubahan tersebut terjadi karena adanya organisme makrobenthos dan pengaruh fisika seperti pengikisan oleh angin dan pergerakan molekul air yang terjadi pada saat pasang. Perubahan fisik serasah daun $R$. apiculata yang mengalami dekomposisi dapat dilihat pada Gambar 2.

Hasil pengamatan penurunan bobot kering serasah daun R. apiculata (Gambar 3) menunjukkan adanya penurunan bobot yang sangat cepat terjadi pada hari ke 15 dibandingkan setelah hari ke 30 , kemudian melambat sampai hari ke 45 dan cepat kembali sampai akhir penelitian pada hari ke 90 . Kondisi tersebut diduga terjadi karena serasah yang masih baru masih banyak persediaan unsur-unsur yang merupakan makanan bagi mikroba tanah atau bagi organisme pengurai, sehingga serasah cepat hancur.

Hal ini sesuai dengan pernyataan Apdhan et al. (2013) bahwa laju dekomposisi tertinggi terjadi pada tahap awal, hal ini diduga berhubungan erat dengan kehilangan bahan organik dan anorganik yang mudah larut (pelindihan) dan juga hadirnya mikroorganisme yang berperan dalam perombakan beberapa zat yang terkandung dalam daun mangrove. Semakin lama waktu proses, semakin turun kecepatan per harinya. Hasil penelitian yang sama juga dilaporkan oleh Sa'ban et al. (2013), bahwa laju dekomposisi serasah daun yang terdekomposisi dan sisa serasah daun dan spesies S. alba dan R. apiculata, terdekomposisi sangat cepat pada 15 hari dibandingkan setelah hari ke-30 hari, kemudian melambat sampai ke-45 hari dan cepat kembali sampai akhir penelitian pada hari ke-60 hari, $R$. apiculata juga terdekomposisi dengan cepat sampai akhir ke-75 hari.

Hasil pengamatan persentase serasah yang tertinggal dalam kantong pada Gambar 4 menunjukkan bahwa pada hari ke 90 persentasenya stasiun I sebesar $4,47 \%$, stasiun II sebesar $6,6 \%$ dan stasiun III sebesar $8,73 \%$. Kondisi tersebut menunjukkan bahwa persentase terendah terdapat pada stasiun I dikarenakan lokasinya yang berada paling dekat dengan laut sehingga lebih lama terendam oleh adanya air pasang. Hal ini sesuai dengan pernyataan Arief (2003) bahwa peristiwa pasang surut membantu terjadinya proses dekomposisi melalui pelapukan. Bersama-sama dengan kadar garam dan sinar matahari, secara lambat pasang surut menghancurkan bahan-bahan organik tersebut.

Persentase dekomposisi tertinggi setelah 90 hari pengamatan terletak pada stasiun I dengan nilai 95, 53\% (Tabel 2). Kondisi tersebut di duga karena stasiun I berada pada daerah yang paling dekat dengan laut sehingga faktor lingkungan terutama mekanisme fisik juga ikut membantu proses dekomposisi menjadi lebih cepat bila dibandingkan dengan stasiun II dan stasiun III. Hal ini sesuai dengan pernyataan Sa'ban et al. (2013) bahwa di daerah perairan proses dekomposisinya juga dibantu oleh mekanisme fisik yakni pergerakan arus pasang dan penggenangan oleh air laut yang lebih lama. Mekanisme hilangnya bahan-bahan yang dapat larut dari serasah yang 
disebabkan oleh hujan atau aliran air. Menurut Mason (1978) penguraian serasah juga dapat disebabkan oleh pengikisan serasah oleh pergerakan gelombang. Kondisi substrat perairan yang lebih lembab dibandingkan daratan juga berperan dalam menguraian serasah, nilai $\mathrm{pH}$ 7-8 menunjukan lingkungan yang selalu basa dan lembab nilai menyebabkan proses dekomposisi serasah cepat.
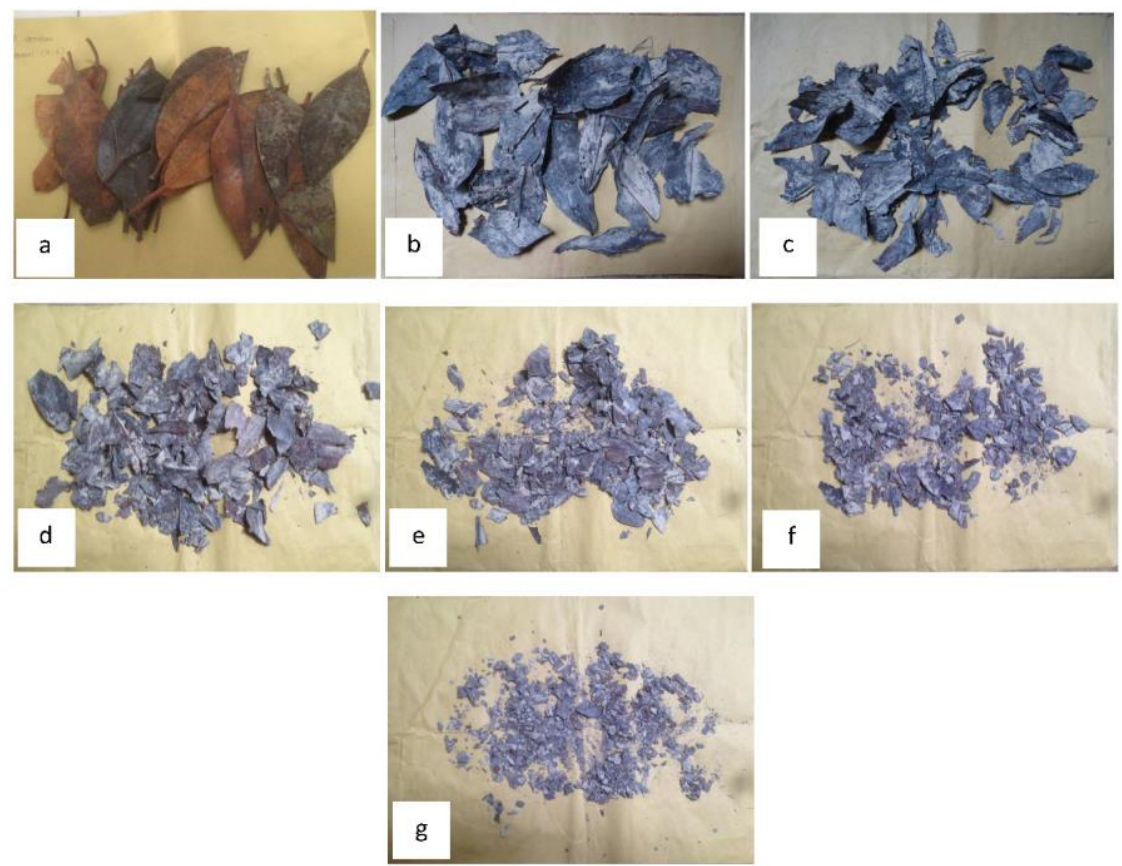

Gambar 2. Bentuk serasah daun mangrove Rhizophora apiculata yang mengalami proses dekomposisi selama 90 hari dalam periode 0 - 90 hari. (a) 0 hari; (b) 15 hari; (c) 30 hari; (d) 45 hari; (e) 60 hari; (f) 75 hari; (g) 90 hari.

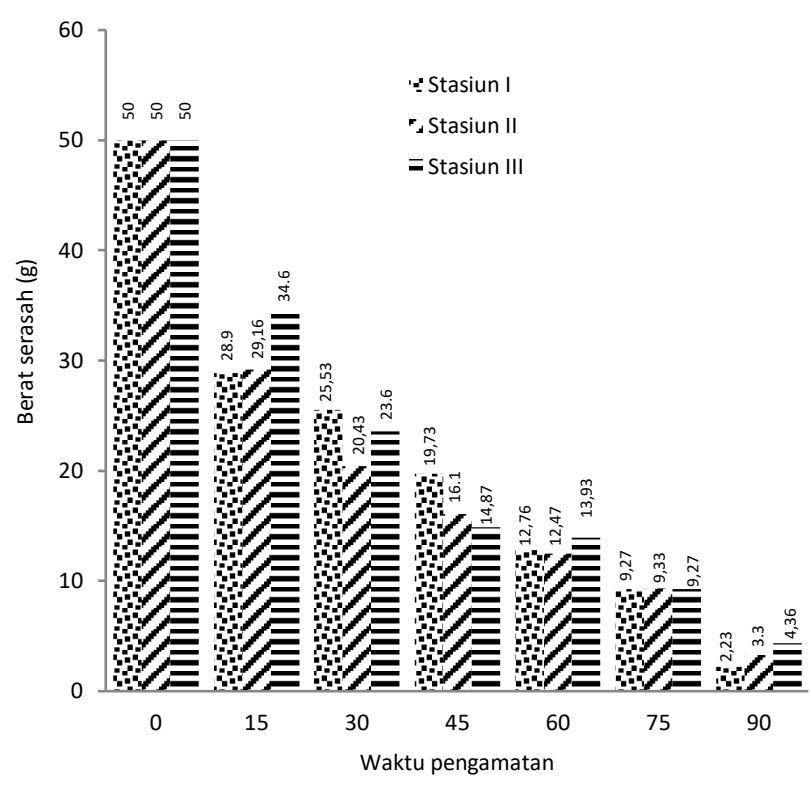

Gambar 3. Rata-rata serasah daun mangrove Rhizophora apiculata selama periode pengamatan 90 .

Tabel 2.

Persentase dekomposisi serasah daun Rhizophora apiculata

\begin{tabular}{ccccccc}
\hline \multirow{2}{*}{ Stasiun pengamatan Persentase dekomposisi (\%) } \\
\cline { 2 - 7 } & 15 & 30 & 45 & 60 & 75 & 90 \\
\hline I & 42,2 & 48,93 & 60,53 & 74,47 & 81,47 & 95,53 \\
Ii & 41,66 & 59,14 & 67,8 & 75,06 & 81,34 & 93,4 \\
lii & 30,8 & 52,8 & 70,26 & 72,14 & 81,46 & 91,26 \\
\hline
\end{tabular}

Nilai konstanta laju dekomposisi (k) serasah daun Rhizophora apiculata pada Gambar 5 menunjukkan bahwa nilai tertinggi dari 90 hari pengamatan terdapat pada stasiun I sebesar 13,04 dan terendah pada stasiun III sebesar 10,24. Kondisi tersebut diduga karena stasiun I diketahui memiliki substrat berlumpur yang cukup dalam. Hal ini mendukung untuk makrobenthos berkembang di stasiun I. Makrobenthos berperan penting dalam penguraian serasah pada saat mengalami dekomposisi, sehingga pada daerah yang banyak dijumpai makrobenthos laju dekomposisi cepat berlangsung. Menurut Syamsurisal (2011) bahwa mikroba (dekomposer) banyak terdapat di daerah bersubtrat lumpur. Selain itu substrat lumpur yang dalam pada stasiun I mendukung pertumbuhan $R$. apiculata yang lebih optimal dikarenakan $R$. apiculata menyukai substrat berlumpur. Hal ini sejalan dengan penelitian yang dilakukan oleh Amin et al. (2015) nilai rata-rata $R$. apiculata menurun jumlahnya pada substrat yang komposisi lumpurnya rendah / berkarakter keras dan cenderung kasar (pasir, pasir berlumpur dan pasir berbatu). Spesies ini umumnya tumbuh pada tanah berlumpur, halus, dalam dan tergenang pada saat pasang normal. Menurut Noor et al. (1999) Rhizophora apiculata tidak menyukai substrat yang keras.

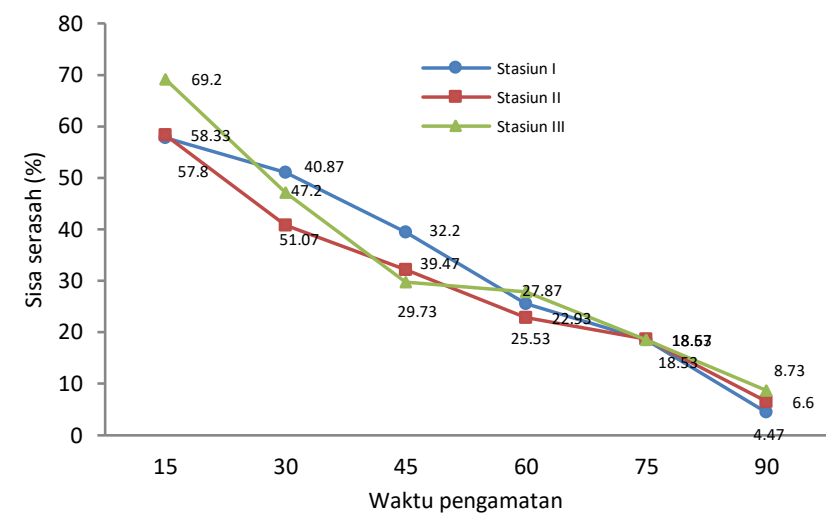

Gambar 4. Persentase serasah yang tertinggal dalam kantong.

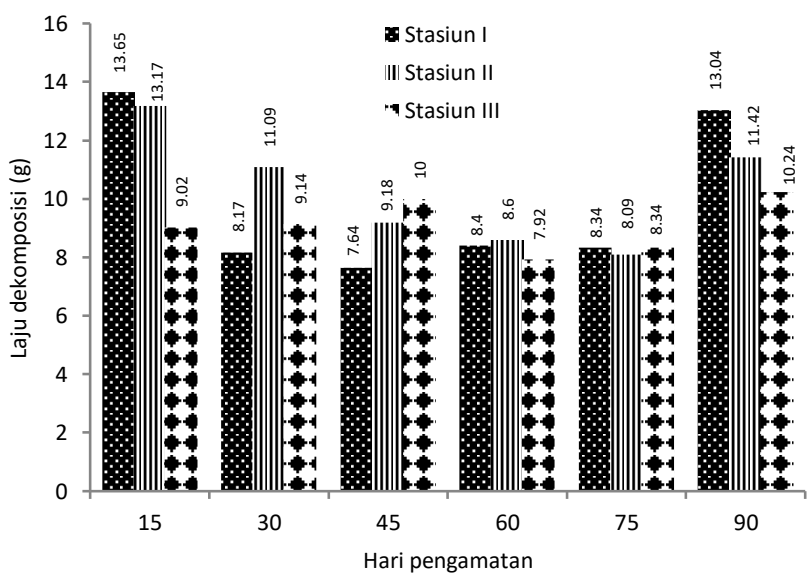

Gambar 5. Nilai konstanta rata-rata laju dekomposisi (k) serasah daun Rhizophora apiculata. 


\subsection{Kandungan unsur hara $(C, N$, dan $P)$}

Serasah mengandung unsur hara yang berperan dalam pembentukan pertumbuhan dan perkembangan tumbuhtumbuhan, ikan, udang, kepiting dan mikroorganisme lainnya di hutan mangrove. Serasah yang memiliki kandungan unsur hara yang tinggi akan lebih cepat mengalami proses dekomposisi. Hal ini sesuai dengan Waring dan Schlesinger, (1985) yang menyatakan bahwa Serasah yang kaya nutrisi cenderung lebih cepat terdekomposisi daripada serasah yang miskin nutrisi pada lantai hutan yang sama. Menurut Ulqodry (2008), bahwa kualitas nutrisi yang tinggi akan menghasilkan proses dekomposisi yang lebih cepat. Kandungan unsur hara yang dianalisis meliputi karbon, nitrogen dan fosfor. Berdasarkan Gambar 6 kandungan unsur hara karbon memiliki nilai yang tertinggi dibandingkan dengan nitrogen dan fosfor. Hasil penelitian ini sejalan dengan hasil penelitian yang dilaporkan oleh Yulma (2012), bahwa kandungan bahan organik karbon (C) pada serasah mangrove jauh lebih besar dari kandungan nitrogen $(\mathrm{N})$ dan posfor $(\mathrm{P})$.

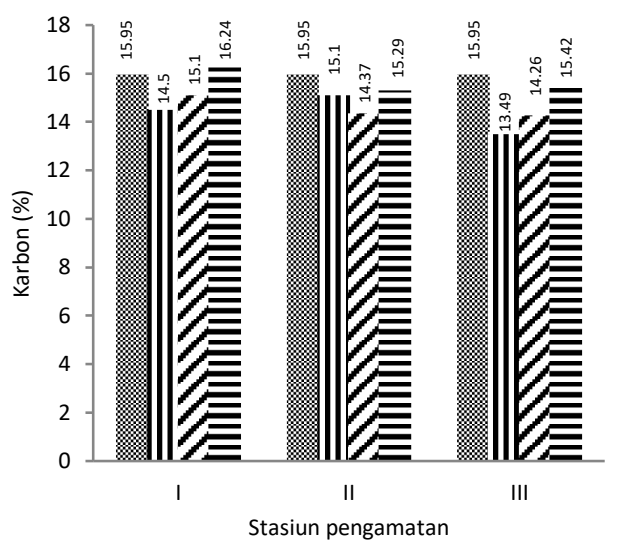

冈 Hari ke 0

I Hari ke 30

Hari ke 60

= Hari ke 90

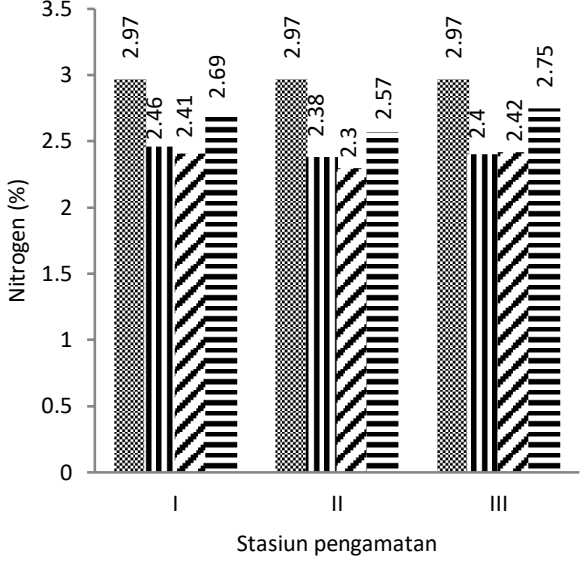

: Hari ke 0

I Hari ke 30

. Hari ke 60

- Hari ke 90

Hari ke

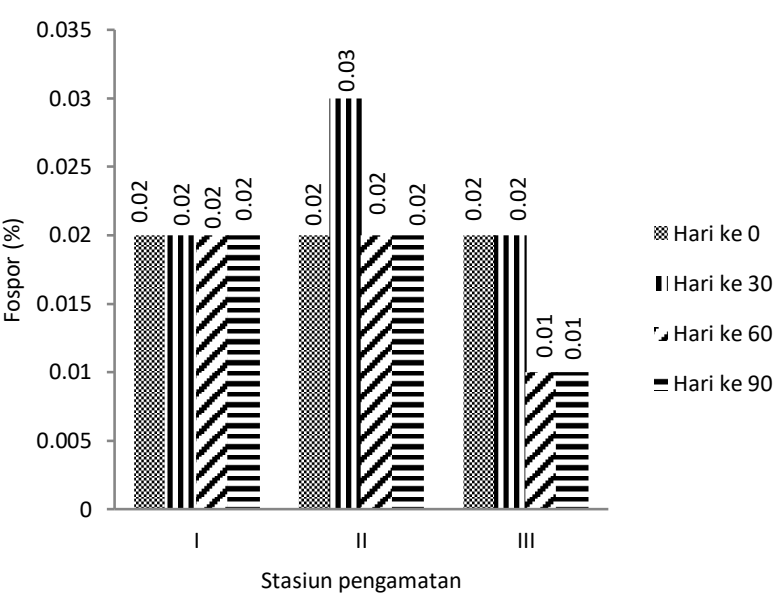

Gambar 6. Kandungan unsur hara C, N, dan P pada daun mangrove Rhizophora apiculate yang telah mengalami dekomposisi.
Dari pengukuran Karbon (C) dan Nitrogen (N) dapat diketahui pula nilai rasio $\mathrm{C} / \mathrm{N}$ yang dimiliki serasah daun mangrove $R$. apiculata yang telah terdekomposisi. Rasio $\mathrm{C} / \mathrm{N}$ tertinggi terdapat pada hari ke 30 di stasiun II dengan nilai 6,34 dan terendah 5,62 yang terletak pada stasiun III hari ke 90 . Rasio $\mathrm{C} / \mathrm{N}$ yang rendah menunjukkan bahan organik sudah sangat matang dan menunjukkan tingkat kecepatan substrat terdekomposisi. Sesuai dengan pernyataan Rindyastuti dan Agung (2010) menerangkan bahwa besarnya nilai awal dan penurunannya akan berkorelasi dengan cepat dan lambatnya proses dekomposisi karena semakin rendah nilai $\mathrm{C} / \mathrm{N}$, semakin baik kandungan unsur hara $\mathrm{N}$ disebabkan oleh kemampuan bakteri nitrogen pada serasah daun untuk melakukan fiksasi nitrogen. Rasio C/N R. apiculata dapat dilihat pada Gambar 7.

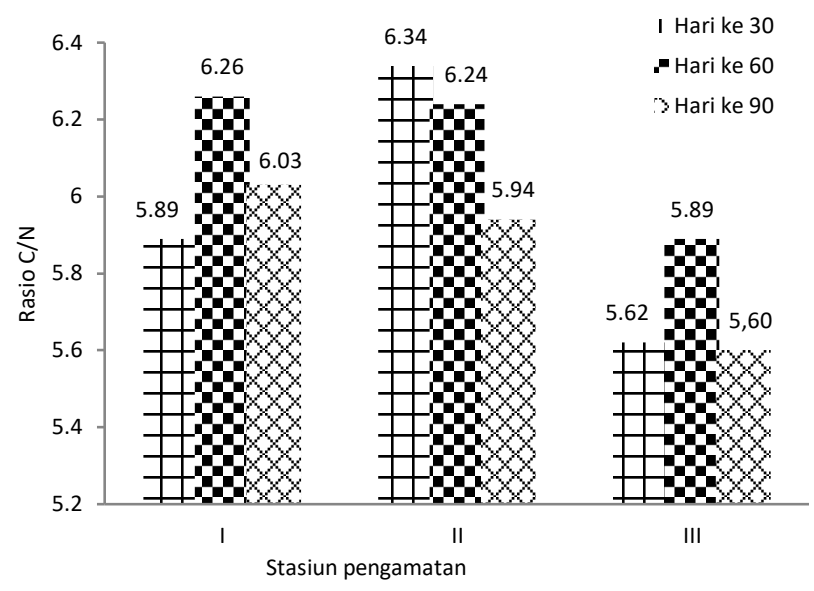

Gambar 7. Rasio C/N.

\subsection{Makrobenthos}

Makrobenthos yang terdapat pada kantong serasah daun mangrove $R$. apiculata lebih banyak ditemukan pada stasiun I dibandingkan dengan stasiun yang lainnya. Jenis makrobenthos yang terdapat pada kantong serasah dapat dilihat pada Tabel 3.

Tabel 3.

Jenis-jenis makrobenthos yang ditemukan di dalam kantong serasah daun Rhizophora apiculate

\begin{tabular}{lcc}
\hline \multicolumn{1}{c}{ Kelas } & Ordo & Genus \\
\hline Turbellaria & Eunicida & Lumbrineris \\
Gastropoda & Sorbeoconcha & Littoraria \\
Malacostraca & Decapoda & Acetes \\
Crustacea & Decapoda & Uca \\
\hline
\end{tabular}

Makrobenthos yang terdapat di dalam kantong serasah pada Tabel 4 yaitu kelas Turbellaria, Gastropoda, Malacostraca, Crustacea. Keanekaragaman makrobentos terdapat pada semua stasiun, tetapi kelimpahan makrobentos terdapat pada stasiun I. Banyaknya makrobentos di dalam kantong serasah dipengaruhi oleh tingkat salinitas, dimana stasiun I berada di dekat pantai dengan substrat lumpur yang tebal dan dipengaruhi arus yang cepat. Tingginya bahan organik yang terdapat pada stasiun I dan faktor lingkungan yang mendukung pertumbuhannya. Keberadaan makrobenthos tersebut berfungsi sebagai perombak bahan organik dalam proses dekomposisi. Hal ini sesuai Arief (2003), bahwa keberadaan makrobentos mempercepat proses dekomposisi. Menurut siddiqui et al. (2009) bahwa kepadatan makrobentos mempengaruhi laju dekomposisi. Kehidupan makrobentos dipengaruhi oleh kondisi lingkungan dan semakin tinggi suhu akan meningkatkan aktivitas makrobentos yang juga akan mempercepat laju dekomposisi. 


\subsection{Parameter fisika dan kimia perairan}

Pengukuran parameter fisika dan kimia perairan pada tiap stasiun dilakukan sebanyak 6 kali pengukuran. Parameter fisika kimia yang diukur adalah: suhu, salinitas, oksigen terlarut, dan $\mathrm{pH}$. Pada setiap stasiun di lokasi penelitian memiliki perbedaan nilai parameter fisika kimia perairan. Kisaran dan nilai rata-rata parameter fisika kimia perairan di lokasi penelitian disajikan pada Tabel 4.

Tabel 4.

Hasil pengukuran parameter fisika kimia perairan

\begin{tabular}{lcccccc}
\hline \multirow{2}{*}{$\begin{array}{l}\text { Parameter } \\
\text { fisika kimia }\end{array}$} & \multicolumn{2}{c}{ Stasiun I } & \multicolumn{2}{c}{ Stasiun II } & \multicolumn{2}{c}{ Stasiun III } \\
\cline { 2 - 7 } & Kisaran & $\begin{array}{c}\text { Rata- } \\
\text { rata }\end{array}$ & Kisaran & $\begin{array}{c}\text { Rata- } \\
\text { rata }\end{array}$ & Kisaran & $\begin{array}{c}\text { Rata- } \\
\text { rata }\end{array}$ \\
\hline $\begin{array}{l}\text { Suhu }\left({ }^{\circ} \mathrm{C}\right) \\
\text { Salinitas }\end{array}$ & $30-32$ & 31 & $27-32$ & 30,33 & $28-33$ & 30,33 \\
(ppt) & $7-16$ & 12,33 & $5-15$ & 10,17 & $5-14$ & 9 \\
$\mathrm{pH}$ & $6,1-7,8$ & 7,03 & $6,5-7,9$ & 7,28 & $6,4-7,8$ & 7,2 \\
$\mathrm{DO}(\mathrm{mg} / \mathrm{l})$ & $2,0-3,3$ & 2,75 & $2,0-3,5$ & 2,85 & $2,0-3,0$ & 2,4 \\
\hline
\end{tabular}

Suhu tertinggi terdapat pada stasiun III sebesar $33^{\circ} \mathrm{C}$, hal ini dikarenakan oleh pengukuran suhu yang dilakukan pada saat siang hari. Faktor lainnya adalah letak stasiun III adalah daerah terbuka sehingga intensitas cahaya yang diterima tinggi dan stasiun tersebut memiliki kedalaman yang rendah sehingga penetrasi cahaya matahari masih dapat menembus dasar perairan. Nilai suhu terendah terdapat pada stasiun II sebesar $27^{\circ} \mathrm{C}$. Rendahnya suhu diakibatkan karena pada saat pengukuran bertepatan saat hujan turun yang mengakibatkan suhu pada perairan tersebut rendah. Selain itu penutupan vegetasi mangrove juga dapat mempengaruhi pemasukan cahaya matahari kedalam perairan yang menyebabkan suhu rendah. Menurut Halidah et al. (2007) bahwa semakin besar persentase penutupan vegetasi maka semakin rendah temperatur dalam air. Keberadaan vegetasi sangat membantu dalam mengurangi penyerapan cahaya, sehingga suhu pada permukaan perairan tidak terlalu tinggi.

Saat pengukuran nilai salinitas yang didapat pada masing-masing stasiun pada Tabel 4 berkisar antara 5-16 ppt. Hasil nilai kisaran salinitas antar stasiun yaitu pada stasiun I 7-16 ppt, stasiun II 5-16 ppt dan stasiun III 5-14 ppt. Pohon mangrove mempunyai daya adaptasi yang khas yang sesuai dengan habitat yang dipengaruhi oleh pasang surut dan salinitas. Menurut Arksonkoe (1993), salinitas merupakan faktor lingkungan yang sangat menentukan perkembangan hutan mangrove, terutama bagi laju pertumbuhan, daya tahan dan zonasi spesies mangrove. Menurut Arief (2003) pasang surut berkaitan dengan salinitas, tingkat frekuensi pasang surut sangat ikut menentukan adanya perubahan salinitas. Semakin sering terjadi pasang surut, tingkat salinitas semakin meningkat. Pengaruh salinitas terhadap kepadatan makrobentos (dekomposer) terjadi secara tidak langsung, yaitu melalui kerapatan pohon yang mengakibatkan suatu tunjangan bagi kenaikan kepadatan makrobentos.

Nilai kisaran salinitas tertinggi terdapat pada stasiun I yaitu 7-16 ppt disebabkan oleh letak stasiun I yang dekat pantai sedangkan yang terendah terdapat pada stasiun III dengan nilai 5-14 ppt. Hasil tersebut terbilang rendah diduga karena lokasinya yang dekat dengan muara sungai. Hal ini sesuai dengan Rosmaniar (2008), adanya penambahan air tawar yang mengalir masuk ke perairan laut melalui muara sungai akan menurunkan nilai salinitas. Menurut Ramli et al. (2011) bahwa di daerah yang terdapat aliran sungai akan terjadi percampuran dua atau lebih massa air yang berbeda sifatnya. Hal inilah yang menyebabkan penurunan salinitas air laut sebagai akibat masuknya air tawar ke perairan. Salinitas optimum yang dibutuhkan mangrove untuk tumbuh berkisar antara 10-30 ppt (Alwidakdo et al., 2014).
Nilai pH tertinggi pada Tabel 4 terdapat pada stasiun II sebesar 7,9. Nilai $\mathrm{pH}$ terendah terdapat pada stasiun I sebesar 6,1 . Kondisi perairan tersebut cenderung bersifat asam, sifat sangat asam maupun sangat basa membahayakan kelangsungan hidup organisme karena menyebabkan terjadinya gangguan metabolisme dan respirasi. Hal ini sesuai dengan Prescott et al. (2004) yang menyatakan bahwa $\mathrm{pH}$ suatu perairan merupakan salah satu parameter yang penting dalam pemantauan kualitas perairan. Organisme perairan memiliki kemampuan yang berbeda dalam mentoleransi $\mathrm{pH}$ perairan. Batas toleransi organisme perairan terhadap $\mathrm{pH}$ bervariasi dan dipengaruhi oleh banyak faktor, antara lain suhu, oksigen terlarut, alkalinitas, adanya berbagai anion dan kation serta jenis stadia organisme. Menurut Nuriyawan et al. (2016) organisme perairan memiliki kemampuan yang berbeda dalam mentoleransi $\mathrm{pH}$ perairan.

Oksigen terlarut berperan dalam proses dekomposisi karena makrobentos sebagai dekomposer membutuhkan oksigen untuk kehidupannya. Nilai DO yang didapat saat penelitian pada Tabel 4 bervariasi setiap stasiunnya berkisar 2,0 $\mathrm{mg} / \mathrm{l}-3,5 \mathrm{mg} / \mathrm{l}$. Nilai DO tertinggi terdapat pada stasiun II dengan nilai rata-rata sebesar $3,5 \mathrm{mg} / \mathrm{l}$ dan nilai $\mathrm{DO}$ terendah terdapat pada semua stasiun pengamatan dengan nilai rata-rata sebesar $2,0 \mathrm{mg} / \mathrm{l}$. Variasi tersebut diduga karena adanya perbedaan waktu pengukuran dan perbedaan musim. Sesuai dengan literatur Lekatompessy dan Alfredo (2010) kadar DO di perairan juga berfluktuasi secara harian, tergantung pada percampuran (mixing) dan pergerakan massa air (turbulence), aktivitas fotosintesis dan respirasi serta masukan limbah kedalam air.

\section{Kesimpulan}

Laju dekomposisi serasah daun R.apiculata pada hari ke90 yaitu pada stasiun I bernilai 13,04 stasiun II bernilai 11,42 dan stasiun III bernilai 10,24. Laju dekomposisi tercepat ialah pada stasiun I dengan nilai 13,04 dan laju dekomposisi terlama terdapat pada stasiun III dengan nilai 10,24. Kandungan unsur hara karbon selama proses dekomposisi 90 hari yaitu stasiun I sebesar $16,24 \%$, stasiun II sebesar 15,29\% dan stasiun III sebesar $15,42 \%$. Unsur hara nitrogen yang terdekomposisi pada hari ke 90 yaitu stasiun I sebesar 2,69\%, stasiun II sebesar 2,57\% dan stasiun III sebesar $2,75 \%$. Kandungan unsur hara fosfor selama proses dekomposisi 90 hari yaitu stasiun I 0,02 \%, stasiun II 0,02 $\%$ dan stasiun III 0,01\%.

\section{Bibliografi}

Alwidakdo, A., Z. Azham, dan Kamarubayana, L., 2014. Studi Pertumbuhan Mangrove pada Kegiatan Rehabilitasi Hutan Mangrove di Desa Tanjung Limau Kecamatan Muara Badak Kabupaten Kutai Negara. Jurnal AGRIFOR. 13(1): 11-18.

Amin, D. N., H. Irawan, dan Zulfikar, A., 2015. Hubungan Jenis Substrat dengan Kerapatan Vegetasi Rhizophora sp. di Hutan Mangrove Sungai Nyirih Kecamatan Tanjungpinang Kota Tanjungpinang. Universitas Maritim Raja Ali Haji. Tanjungpinang.

Apdhan, D., A. Mulyani, dan Zulkifli, 2013. Produksi dan Kandungan Karbon Serta Laju Dekomposisi Serasah Xylocarpus sp. di Perairan Sungai Mesjid Dumai. Riau. 111.

Arief, A., 2003. Hutan Mangrove Fungsi dan Manfaat. Kanisius. Yogyakarta. 
Boonruang, P., 1984. The Rate of Degradation of Mangrove Leaves, Rhizhophora apiculata and Avicennia marina (forsk) vierh at Phuket Island, Western Peninsula of Thailand.

Halidah, M. Qiptiyah, dan Anwar, C., 2007. Produktivitas Tambak pada Berbagai Penutupan mangrove. Info Hutan. IV (4): 409-417.

Lekatompessy, S. T. A dan Tutuhatunewa, A., 2010. Kajian Konstruksi Model Peredam Gelombang dengan Menggunakan Mangrove di Pesisir Lateri - Kota Ambon. Arika. 4(1): 52-60.

Mason, C.F., 1978. Decomposition. The Institute of Biology. Studies In Biology No. 74. Edward Arnold. London.

Noor, Y. R., M. Khazali dan Suryadiputra, I.N.N., 1999. Panduan Pengenalan mangrove di Indonesia. Wetlends Internasional-Indonesia Programe. Bogor.

Nuriyawan, A., A. Rafi'i, dan Abdunnur, 2016. Peranan Serasah Mangrove (Rhizopora mucronata) dalam Tambak Udang Model Wanamina Terhadap Fluktuasi Kualitas Air Tambak di Desa Saliki Kecamatan Muara Badak, Kabupaten Kutai Kartanegara. Jurnal IImu Perikanan Tropis. 22(1): 54-63.

Olson, J. S., 1963. Energy Storage and the Balance of Producer and Decomposers in Ecological Systems. Ecology 44 : 322-331.

Prescott, C. E., L.L. Blevins, and Staley, C., 2004. Litter Decomposition in British Columbia Forests: Controlling Factors and Influences of Forestry Activities. Journal of Ecosystems and Management 5(2):44-57.

Ramli, M., D. G. Bengen, R. F. Kaswadji, dan Affandi, R., 2011. Sumberdaya Detritus dari Hutan Mangrove Sebagai Makanan Potensial Ikan Belanak (Liza subviridis) di Pantai Utara Konawe Selatan Sulawesi Tenggara. Jurnal AGRIPLUS. 21(1): 178-184.

Rosmaniar, 2008. Kepadatan dan Distribusi Kepiting Bakau (Scylla spp.) serta Hubungannya dengan Faktor Fisika Kimia di Perairan Pantai Labu Kabupaten Deli Serdang. [Tesis]. Universitas Sumatera Utara. Medan.

Rindyastuti, R. dan Darmayanti, A.S., 2010. Komposisi Kimia dan Estimasi Proses Dekomposisi Serasah 3 Spesies Familia Fabaceae di Kebun Raya Purwodadi. Seminar Nasional Biologi. Universitas Gadjah Mada. Yogyakarta.

Sa'ban, M. Ramli dan Nurgaya, W., 2013. Produksi dan Laju Dekomposisi Serasah Mangrove dengan Kelimpahan Plankton di Perairan Mangrove Teluk Moramo. Jurnal Mina Laut Indonesia. 3 (12): 132-146.

Siddiqui, P. J. A., Zafar, F., Ehsan, E. V., Munawwer, R., Sheema, S., 2009. Studies on Decomposition Rates of Avicennia and Rhizophora Leaves on Tidal Mudflats in Active Indus Deltaic Area of Pakistan. Journal Int. J. Phycol. Phycocem. 5(1) : 93-98.
Syamsurisal, 2011. Studi Beberapa Indeks Komunitas Makrozoobenthos di Hutan Mangrove Kelirahan Coppo Kabupaten Barru. Universitas Hasanuddin. Makassar.

Ulqodry, Z.T., 2008. Produktivitas Serasah Mangrove dan Potensi Kontribusi Unsur Hara di Perairan Mangrove Tanjung Apiapi Sumatera Selatan. [Tesis]. Intitut Pertanian Bogor. Bogor.

Waring and Schlesingan, 1985. Forest Ecology Concept and Management. Akademic Press. Inc, Orlando.

Yulma, 2012. Kontribusi Bahan Organik dari Mangrove Api-Api (Avicennia marina) Sebagai Bahan Evaluasi Pengelolaan Ekosistem Mangrove. [Tesis]. Institut Pertanian Bogor. Bogor. 